\title{
INTERVIEW
}

\section{PER AAGE BRANDT}

Interviewet af Finn Kjær Jensen

\section{KULTURREALISME}

I dette interview plæderer semiotikprofessoren Per Aage Brandt vedvarende for en rationel og teoretisk åben holdning $\mathrm{i}$ humanvidenskaberne. Videnskabelig universalisme og realisme er et godt alternativ til de forskellige fremherskende skepticistiske erkendelsesteorier: kulturrelativisme, dekonstruktivisme, socialkonstruktivisme og så videre. Per Aage Brandt argumenterer således for hvorledes Tegn, Ting og Tanker (titlen på hans seneste bog) forbindes i en semiotisk og antropologisk realisme. At verden fortløbende må medtænkes demonstreres gennem eksempler.

\section{Det man tror om verden}

Der er ingen grund til tфven: Hvad er videnskabsteori?

Videnskabsteori er i praksis, som den udøves og formidles i universitær humanistisk sammenhæng i forbindelse med disciplinerne, forskellig fra fag til fag. Kernen i den er og bliver metodologien. Men metodologien rejser samtidig alle de ontologiske spørgsmål, for så vidt den metode, man vælger, jo udtrykker det man tror om genstanden. $\mathrm{Og}$ selve dette argument er en videnskabsteoretisk konstant.

Antropologien må altså spфrge sig selv om...?

Man spørger hvad det egentlig er man unders $ø$ ger - hvordan man egentlig tror man barer sig ad med det. Jeg ville jo kalde antropologien en komparativ videnskab. Man bringer sig i besiddelse af empirisk viden om forskellige kollektiver, samfund, og sammenligner deres adfærd. Deres adfærd, både mentalt, socialt og fysisk; specielt det fænomen, at vi finder ,sociale institutioner“, eller hvad man nu vil kalde sådan nogle, når de ikke ligefrem er nedfældet i paragraffer, sådan som de er i de moderne samfund. Man skaffer sig et komparativt begreb om forskellige samfundsformer. Det første spørgsmål i denne forbindelse er naturligvis, hvad det så er man komparerer? Hvad er det man sammenligner?

Ja, og hvordan gфr man det?

Det kommer simpelthen an på, hvad det „er“, man har fat i. Hvis man nu for eksempel tror eller antager at alle samfund har en juridisk institution, spørger man folk, hvordan de løser konflikter. Folk spørger fornuftigvis tilbage: Hvilke konflikter? Og så kan man jo prøve sig frem: For eksempel konflikter med hensyn til hvem der skylder hvem noget. 
Eller med hensyn til behandlingen af det, som opfattes som forbrydelser. Er forbrydelser $i \emptyset v r i g t$ et stabilt emne at spørge på? Det er det formentlig - i en vis forstand. Hvis det er et stabilt emne, er der så andre stabile emner? Hvis der dukker mange stabile emner op på denne måde, kan man opbygge en mere eller mindre stabil liste over hypotetiske universalier. Men sådan nogle har unægtelig en ontologisk status. De vil kendetegne menneskets måde at leve sammen med andre mennesker på i det hele taget. Og kendskabet til dette er netop hvad man i meget gamle dage forstod ved antropologi: læren om antropos. Spørgsmålet støder hårdt mod cultural studies-teser om, at der ikke skulle findes sådanne stabile størrelser overhovedet. Kulturer skulle simpelthen relativt til sig selv skabe deres egne, helt originale emner, således at stabiliteten kun kunne holde indtil kulturens grænser, den enkelte kulturs grænser, nås; i så fald har vi at gøre med en kulturrelativisme, en holdning og metode, der derfor ikke kan blive komparativ. På denne måde handler epistemologien, som man kunne kalde det - læren om hvilke sandheder man er ude efter - både om metodologi og om ontologi. Man vipper hele tiden fra det metodologiske til det ontologiske og tilbage igen. Men hvilke metoder anerkender man egentlig, når man hylder en kulturrelativ opfattelse? Man er vel henvist til en impressionistisk indfølingsmetode.

Impressionisme er, hvad man efterlades med, hvis ikke man anerkender universalier og vil privilegere synsvinkler?

Ja, enkelt sagt. Cultural studies-antropologien kommer nu i vanskeligheder, fordi den er nødt til at forklare sig selv, hvilken indføling man i så fald må stole på. I det hele taget kan man sige, at videnskabsteorien må handle om hvad det er vi stoler på, når vi forsker. Hvad stoler vi overhovedet på? At vi, trods det faktum at vi antager at et menneske er hvad det er i kraft af en kultur, alligevel vil være i stand til at forstå dette menneske uanset „dets“ kultur - ellers ville vi jo ikke kunne gøre det. I virkeligheden er det umuligt at drive systematisk antropologi i det radikalt relativistiske regi. Problemet er analogt med det gamle paradoks, at vi oversætter; det er ikke desto mindre ,umuligt“ at oversætte, fordi vi tænker i et sprog, og et sprog er begrænset af sine interne strukturer som er forskellige fra ethvert andet sprogs - dets ytringer er uoversættelige. Men det er en kendsgerning, at vi alligevel faktisk oversætter. Det er noget man endda næsten kan leve af. Det går også rimeligt godt med studiet af andre kulturer, i den forstand at det i praksis viser sig at man kan få noget at vide, som man ikke er nødt til at afvise. Hvis man kan sige at resultaterne af en komparativ metode tager sig så solide ud, at man spontant kan tro på dem, og man ikke kan finde gode modargumenter, ja så må man jo tro på dem indtil videre. Det er et lige så godt argument som at oversættelse finder sted og altså findes. I så fald kan vi problematisere den kulturrelativistiske tilgang, der i dag hedder mange ting: dekonstruktivisme, socialkonstruktivisme. Den går overalt ud på, at man vurderer den historiske dimension som afgørende, og hvilken dimension vurderer man så som ikke-afgørende? Den dimension man kan kalde den universalistiske.

\section{Det kulturelle hardware}

Humanvidenskabernes forståelse af det menneskelige kommer jo almindeligvis $i$ stand ved unders $\emptyset$ gelse af menneskers historiske, sociale og kulturelle kontekst. Antyder du, at der er noget, vi overser her: den foreliggende, fysiske, verden, biologien...? 
Vi begynder jo at vænne os til et meget længere perspektiv nu, hvor vi tager forhistorien med. Forhistorisk arkæologi og palæontologi og betragtninger der medtager vor arts evolution gør jo forhistorien til et næsten lige så vigtigt begreb som historien. Det der ikke er historisk er formentlig evolutionært, når det drejer sig om antropologisk empiri. Og hvad kan man så vide om det evolutionære? Denne problematik befinder sig i en voldsom udvikling i øjeblikket, i kraft af en samling af videnskaber der spænder fra neurologien og biologien til lingvistikken, til forskellige former for psykologi...

...og kognitionsvidenskaben?

$\mathrm{Ja}$, her spiller kognitionsvidenskaberne en stadig større rolle, fordi de faktisk synes at få fat i noget nyt. Jeg har lyst til at nævne en hypotese af Leonard Talmy, en tekst, der er under udgivelse: The Cultural Function. Der er ikke mange studier i netop den funktion, han er ude efter her, men der er nogle. Han antager, at der findes en kognitiv kompetence, som gør at mennesker, som endnu ikke er voksne, i en bestemt periode af deres barndom eller ungdom så at sige scanner kulturelt specifik adfærd og installerer den meget dybt i deres neurale udstyr, så den kommer til at virke som en automatisme. Det er ikke en simpel mimetisk, altså efterlignende, ting, det er en selektiv mekanisme i mennesker, som trækker de ting fra i omgivelsernes adfærd, der kunne være personlige, individuelle særtræk, og i stedet fremhæver den kollektive stilistik - altså afsøger adfærdsfeltet på en lang række områder, og som installerer en slags evaluativ mekanisme, der fortæller dem, hvad der er en god eller rigtig måde at gøre ting på og en ikke så god eller rigtig måde at gøre ting på - det drejer sig for eksempel om indtagelse af føde i kollektivt regi, kropsrutiner, for eksempel hygiejne, men også kommunikativ adfærd såsom taleafstande, blufærdighed, både seksuelt og i forbindelse med hvordan kroppen bør bære sig ad i sociale sammenhænge, hvor meget af kroppen der bør vises, hvordan viser man respekt, altså hele høflighedsregisteret. Og sådan noget som hvor meget man må vise af den emotionelle tilstand man eventuelt befinder sig i. Sådanne ting synes at tilegnes og derefter kunne læres til andre. Det vil sige, at det unge menneske scanner tingene ind, kan man sige, og derefter bliver i stand til at gentage dem langsomt og demonstrativt for andre. Den langsomme, demonstrative gentagelse er jo, kan man sige, et praktisk bevis på at der foreligger en normativ adfærd. $\mathrm{Og}$ til sidst er man i stand til at verbalisere gestussen, sådan at man får en sprogligt kritisk, distanceret refleksiv holdning til den. Der synes ligefrem at være tale om en slags adfærdspakke, som ifølge de undersøgelser som Leonard Talmy henviser til, udfoldes på et bestemt tidspunkt i det unge menneskes udvikling, nemlig fra 9-årsalderen til 16-årsalderen.

\section{Det vil sige en slags kulturel engrammeringsperiode?}

$\mathrm{Ja}$, netop, hvis effekt blandt andet er, at når der kommunikeres med nogen, som svarer godt til den kodeks, der installeres, så bliver den effekt, kommunikationen får, større. $\mathrm{Og}$ kommunikation med mennesker, som ikke besidder denne kodeks, bliver væsentligt ringere og svagere, både emotionelt og intellektuelt. Det er jo ganske interessant for for eksempel læreprocesser i forbindelse med integrering af flygtninge i en kultur, som har en anden kodeks. Og det er noget, som formentlig bliver afgørende for et menneskes individuelle skæbne i en bestemt kultur. Undersøgelser går ud på at man følger unge mennesker som er flyttet enten i perioden, før perioden og efter perioden. Det viser sig at hvis et menneske flyttes fra og med 9-årsalderen til en anden kultur, så installerer dette menneske den modtagende kulturs kodeks. Hvis dette menneske senere - efter perioden, det 
vil sige efter 16-årsalderen - flytter tilbage til afsenderkulturen, så vil reintegrering ikke finde sted. Men hvis et menneske efter 16-årsalderen flyttes til en anden kultur og lige så meget senere vender hjem til afsenderkulturen, så reintegreres det fuldstændigt; og skæres perioden af flytningen, får vi kriser. Det er en ,pakke“, kan man sige, af udviklingspsykologisk art, der kan sammenlignes med ,sprogpakken“, som pakkes ud mellem 2årsalderen og 5-årsalderen, hvorefter sproget er installeret. Jeg gætter så på, at der i den mellemliggende periode fra 5 til 9 år, det vi kalder skolealderen, installeres endnu en pakke, nemlig kønsadfærden. Her holder børnene op med at være små nysselige ukønnede, aseksuelle væsener og begynder at få kontrastiv adfærd over for det andet køn, således at der også er en basal kønsadfærd, der installeres lige før den kulturelle adfærd installeres. Tre adfærds-"pakker“" i rækkefølge: Sprog, så køn, så ,etnicitet“, og så er man klar til at få børn og forpligtelser.

\section{Det er jo en interessant konstruktion: sprog, kфn og den kulturelle „pynt"?}

$\mathrm{Ja}$, og vi har muligvis også noget andet lignende før 2-årsalderen, som har med installering af basale evner for empati. Det er formentlig det der går galt når individer senere bliver autister, bortset fra at der kan være genetiske svagheder, der spiller ind. Man kan altså evolutionært betragte mennesket som udstyret med en række epigenetiske „pakker", dispositioner, der udvikles sekventielt. Epigenetiske, det vil sige, som ikke udfolder sig med mindre de bliver stimuleret efter fødslen og frem til voksenalderen i en bestemt eller typisk rækkefølge. „Stadier“, om man vil, men ikke freud'ske.

Men hvad synes at vare logikken i netop den rakkefølge?

Formentlig den, at det ene optimalt netop forudsætter det andet. $\mathrm{Og}$ så fungerer vore hjerner formentlig sådan, at de ikke kan installere det hele på en gang, fordi det ville blive kaotisk. Der findes måske mange individuelle skæbner, som alligevel er nødt til at installere det hele på en gang, triste institutionelle skæbner for eksempel, som ikke får den passende respons i den periode, hvor den pågældende mekanisme optimalt skal modnes.

\section{I hver pakke foreligger der altså en uudfoldet skematik for naste pakke?}

$\mathrm{Ja}$, der ligger en uudfoldet disposition, ligesom i sprogpakken. Man kan sagtens lære at tale senere end i 5-årsalderen, men det kommer til at lyde anderledes. Det er ret interessant, for det betyder da, at de specifikke etniske ejendommeligheder sidder dybere end det sted hvor ideologierne sidder, hvilket er nyt. Ideologier er anskuelsesmængder, som man kan tilegne sig som voksen. Vi er udstyret med noget, som vi inden for affekt-forskningen teknisk kalder passioner ved siden af emotioner og humфrer. Vi begynder nu at forske i affekter inden for den antropologisk orienterede del af semiotikken. Passioner ytrer sig især i to empiriske felter, nemlig i politiske holdninger og i kærlighed. Det er tilsyneladende de to stærkeste motorer i de forhold der får mennesker til for eksempel at bryde op og installere sig i andre, fremmede kulturer i forhold til afsenderkulturen. Man rejser typisk, fordi man er forelsket, og installerer sig i en fremmed kultur og skifter eventuelt endda religion, og det samme gør man af politiske grunde. I øvrigt er affektmønsteret inden for et individs politiske oplevelser og kærlighedsoplevelser fuldstændig parallelle.

\section{Metaforikken er det $i$ hvert fald!}

Ja, det er de samme emotionsforløb jævnfør [Francesco] Alberonis bog om forelskelsen, de samme op- og nedture og så videre i begge tilfælde. 
Det har det rigtignok, og der er mange faktorer i det som kan gøre et voksent individ modtageligt for holdningsændringer; men de foregår på det diskursive og ideologiske plan, hvor man også kan skifte „smag“, som man siger. Og vi har jo længe troet, at de etniske værdidannelser og så videre, herunder nationalisme, hørte til i denne diskursive afdeling, hvor det ikke var noget stort problem at frembringe skift. Det kunne man for så vidt organisere og debattere sig til, hvis man ville. Men hvis det der her siges om kulturfunktionen er rigtigt, har vi faktisk at gøre med meget tungere hardware og ikke med flygtig software som vi kan skifte ud ved hjælp af retorik. Så har vi at gøre med noget der bedre forklarer hvorfor der opstår disse tunge og blodige konflikter, som vi kender i mange transkulturelle sammenhænge. Kulturfunktionen berører dybe og intime ting, for eksempel indlæringsindstillingen, endda så dybt at man simpelthen ikke kan lære, hvis man befinder sig i en sammenhæng som den udfoldede og specificerede etno-pakke ikke anerkender som kommunikativt relevant. Den sidder „dybt i sjælen“ og dens virkninger kan formentlig dæmpes af voksen diskursiv bevidsthed, dæmpes og redigeres en smule, men ikke fjernes. Vi taler om ting, som mennesker er i stand til at slå ihjel for: Etnisk ,rigtighed“- hvordan „man“ bærer sig ad og ikke bærer sig ad. Vi kan her diskutere så meget vi vil, det bider ikke på fænomenet. Det gælder også en mængde æstetiske fænomener i voksenlivet, fænomener som vil høre til den sociale æstetik der fastholdes af den etnokulturelle, kognitive kodeks. Det betyder at præferencer i forbindelse med en lang række social-æstetiske forhold, hvad der opleves som smukt og grimt og så videre, ligger der.

Det er sejere stof end selv antropologer forestiller sig!

Ja, man kan forestille sig, at man efterhånden som forskningen får flere oplysninger om sagen får et større overblik over hvad det mere præcist er for størrelser der rammes af scanningen. De størrelser, der rammes, vil netop være de konstanter, jeg talte om før. Sådan noget som kropshygiejne, bordskik, spisevaner, taleafstand, høflighedsformer; listen er i nogle udgaver oppe på godt 200 emner i øjeblikket, emner som er gode kandidater.

\section{En realistisk antropologi}

Semiotikken er af en eller anden grund aldrig rigtig slået igennem $i$ den danske udgave af antropologien. I hvert fald ikke eksplicit. Hvorledes vil en semiotisk antropologi se ud for dig?

Vel, der ville være to af dem, for der er for mig at se to måder at gå til sagen på. Den kulturrelative og den evolutionært inspirerede, som jeg nævnte. Ligesom der er to semiotikker, en nominalistisk og en realistisk. Den nominalistiske udgave ville støtte cultural studies i den kulturrelative udgave og blive konstruktivistisk og derfor mene at konstanterne er meget tynde og svage, hvis de overhovedet findes. Konstanterne hedder nu ikke mere end udtryk, indhold og tegndannelse. Tegndannelse finder sted i enhver social sammenhæng, ifølge synspunktet, men hvad tegnene kommer til at handle om er underordnet, blot de danner deres forskelsmønstre. Indholdet formes af udtrykket. Den anden udgave ville antage at betydningens indhold er en mere grundlæggende og omfattende emnemængde end udtryksmaterialet. Og udtryksmaterialet dannes her omvendt på grundlag af et indholdsmateriale som er funderet i vor arts måde at gøre erfaringer i ver- 
den på. Vi er jo kropsligt installerede i en verden der ikke afhænger af, om vi udtrykker den, ifølge denne sidste antagelse. Denne semiotik ville derfor alliere sig med de kognitive videnskaber. At vi er kropsligt installerede i verden kan man formulere på mange måder. Man kan tænke på Philosophy in the Flesh af [George] Lakoff og [Mark] Johnson (1999), men man kan også tænke på fænomenologien. Vi har en teknisk specifik udgave under udvikling i den danske semiotik, som jeg bidrager til i øjeblikket, hvor vi undersøger semantiske domæners grundlag. Hypotesen er at der er mere end ét domæne blandt de mest konkrete, som spiller en basal rolle for dannelsen af forståelsesmønstre i menneskets tilegnelse af dets omverden. Denne omverden har en form i forvejen, ifølge denne antagelse, for eksempel er den makrofysiske verden, vi lever i, udstyret med rumlige kvaliteter som gør det hensigtsmæssigt for væsener, der lever i den, at kunne bedømme afstande og repræsentere lokaliteter og deres indbyrdes forhold, sådan at man kan rotere disse repræsentationer og vende kortene i hovedet - så man både kan finde ud og hjem igen. Det skal der formentlig ikke så forfærdelig store neurale systemer til, men det er ikke kun kroppens fysiske interaktion med de geografiske omgivelser, der danner et basalt domæne, det er også den sociale adfærds basale forhold. Vi hører jo til de arter, der ikke kan klare sig uden socialt samkvem. Man har for eksempel brugt udstødning som en form for dødsstraf i alle stammesamfund, jeg kender til. Stenaldersamfundet brugte det jævnfør Cavalli-Sforza. Den kollektive adfærd besidder simpelthen en række basale skematiske rutiner, som man tilegner sig med samme automatik som man tilegner sig tid og rum.

Du argumenterer for at en rakke domaner - for eksempel det makrofysiske - spiller en basal rolle for dannelsen af forståelsesmonstre $i$ den menneskelige tilegnelse af dets omverden, men også det sociale liv har sine basale, ikke-kulturbundne, skematikker, eksempelvis udst $\phi$ delse; her tanker du på udstфdelse som en universel samfundskonstituerende ,social teknologi “?

Ja, den som virker som implicit trussel i enhver social sammenhæng. Man deltager i udvekslingsforhold, og udvekslinger finder sted ud fra implicitte ækvivalentdannelser. Noget er noget andet „værd“, vard og vardi findes formentlig som udtryk i ethvert sprog. Og deltager man ikke ordentligt i udvekslingerne, ja, så er det ud! Retfærdighedsfølelser hører også til fundamental social erfaring. Der må åbenbart gerne dannes hierarkier, men en fundamental retfærdighed regulerer behandlingen af individer og distributionen af goder i det sociale uanset disse hierarkidannelser, i den forstand at retfærdigheden fungerer i specielle udgaver for hvert niveau i hierarkiet. Og denne regulering tilegner man sig, formentlig også gennem den kulturelle funktion; mens evnen til at orientere sig i det fysiske rum er noget der også tilegnes epigenetisk, men på et langt tidligere tidspunkt. Endelig er der evnen til at indstille tegngivningen efter hvem man udveksler tegn med, individuelt, interindividuelt.

En slags framing for udvekslingen?

En skematisk framing inden for et såkaldt empatisk domæne. Almindelig udveksling af goder kræver ikke empati i denne forstand. Den kræver distant høflighed. Hvilket ikke er nogen simpel mekanisme. Men intim adfærd kræver en anden, specifik kompetence, som formentlig påbegyndes installeret meget tidligt $\mathrm{i}$ barndommen. Her er der således tre eksterne domæner, nemlig det makrofysiske, det sociale og det empatiske. Som en fjerde dimension, der også danner en slags domæne - det gør den i hvert fald i sprogenes semantik - kan vi betragte det mentale, der synes at beskæftige sig med at kombinere de op- 
nåede repræsentationer og udvikle en semio-logik, der gør det muligt at flytte erfaringsskemaer fra et domæne til et andet, så der kan sluttes analogisk og generaliseres. Det er det mentale domæne, der ret tidligt gør det muligt for os at skelne mellem drøm og virkelighed. Vi ved, at det er en skrøbelig funktion, fordi psykopatologierne jo kan forstyrre den. Det er også det mentale domæne, der styrer viljen, „volitionen“.

Du argumenterer fortlфbende ud fra en antagelse om, at den menneskelige adfard i enhver forstand simpelthen må agere på grundlag af visse stabiliteter, visse basale domaner, en vis realisme?

$\mathrm{Ja}$, vi regner i forbindelse med enhver vurdering af hvor virkelig en oplevelse er, med sådanne basale domæner som de virkelighedsregioner hvori noget er virkeligt. Hvis jeg vågner op en morgen og siger at jeg har drømt noget, så er det jo sandt at jeg har drømt dette, men det er ikke sandt at de begivenheder og skikkelser der optrådte i drømmen er historiske. Man har troet at det skyldtes at de var begivenheder i en fremtidig verden, at man kunne bruge drømme til at slutte sandt om fremtiden. Under alle omstændigheder har hvert basalt domæne en egen form for realitet; når man danner højere domæner ved kombination af de basale gennem en såkaldt blending, der er af kreativ og langt mere abstrakt karakter, så hviler de stadig på det samme domænegrundlag som mennesker forstår som værende et grundlag hos hinanden. Det vil sige, at når et menneske vurderer et andet menneske som værende ikke-vanvittigt, henviser det til evnen hos det menneske, man interagerer med, til at foretage den samme tilbageføring til de basale domæner. Et menneske der ikke gør det betragtes som vanvittigt, og det findes der så nogle sociale rutiner for omgangen med - forskellige fra kriminalitetsrutinerne, for det er ikke nødvendigvis en udelukkelse, der da finder sted, men undertiden en helliggørelse, en ,indelukkelse“.

Men lad os lige slå fast at du mener, at eftersom vi interagerer på basale domaner, så må dette $n \phi d v e n d i g v i s$ pege i retning af en realistisk antropologi?

Ja, det ville jeg kalde den. En antropologi som ville være en kognitiv videnskab. En meget værdifuld komponent, for så vidt som dens materiale er forskelligt fra alle andres materiale. Det komparative studium, også inden for den enkelte studerede kultur - af metaformængderne, af mytedannelserne og adfærdsformerne - er jo et felt, som er af største betydning for forståelsen af ikke mindst sprogstrukturerne i den samme kultur. Det synes altså ikke længere så håbløst at forestille sig at kulturer danner studérbare og afgrænselige enheder, som man på et tidspunkt har ment, fordi de jo flyder over i hinanden, og hvor sætter man grænserne? Det afgørende nu er ikke at sætte grænser, det er en indsigt vi har fra studiet af kategoridannelse hos mennesker; det afgørende er at der er typiske former, prototypiske former. Grænserne må gerne være flydende, bare kernerne ikke er flydende.

Tilbage om man vil er variationerne og transformationerne?

Og interaktionerne mellem former. Blendingerne, de historiske rekombinationer af erfaringer, de kreative processer.

\section{Et semiotisk kulturbegreb}

\section{Lad os da narme os et bud på et muligt semiotisk kulturbegreb?}


Ja, forslag findes der jo mange af. Juri Lotman var en af leverandørerne. Han forestillede sig at man i en semiosfære - et sted under atmosfæren og over den basale fænomenologis sfære - har en kulturel regulering af værdier og fortælleformer og andre diskursive størrelser. Dette svævende semiotiske kulturbegreb har ligesom mange andre kulturbegreber hvilet på den diskursive forudsætning, der jo havde den tiltrækkende fordel at man jo her, i diskursen, ville kunne regne med hurtige historiske ændringer i kulturtilstanden: Det var ikke så svært at forandre verden når blot man var aktiv i den... Her blev kulturbegrebet altså et ret let, flygtigt begreb.

Med kultur refererede han til kollektiv erindring, diskursivt overført erindring.

Netop. Men dybere end den kollektive erindring ligger den kollektive anerkendelse af mentale processer i kollektivets menneskelige deltagere, og af de samme domæner, og de samme semio-logikker og så videre.

\section{Erindringens neurale råmateriale?}

$\mathrm{Ja}$, erindringen er jo tvetydig fordi den både er historisk erindring og evolutionær præerindring. Og den sidste danner meget tungere komponenter. De nye tendenser i studiet af etniske forhold hviler på det meget tungere kulturbegreb og fører til nogle tungere, $\mathrm{i}$ $\emptyset$ vrigt mere ubehagelige antagelser. At de voldsomme følelser, som vækkes af konflikter inden for det samme territorium udløst af forskelligartet adfærd, er langt vanskeligere at indgribe i. At det er langt vanskeligere at ændre menneskers kulturelle adfærd end hidtil antaget, fordi den simpelthen ligger som kognitive automatikker installeret i selve den menneskelige opmærksomhedsstruktur. Opmærksomhed, attention, er en faktor, som ganske vist opleves som en let og foranderlig størrelse, men det er i virkeligheden en uhyre tung og træg mekanisme: den har en ,profil“, som sorterer i det, den rettes imod; og som er ,tungt" kulturel.

\section{Opmærksomhedsfællesskaber}

Hvilket retter min opmarksomhed mod, at du i dit forord til din oversattelse af MerleauPontys Om sprogets fænomenologi beskriver kulturer som en slags opmarksomhedsfallesskaber. Kan du uddybe dette?

Kulturer indebærer sammenkoblingen af opmarksomheder, og det, det nu drejer sig om, er betingelserne for bevidsthedernes kognitive samarbejde gennem disse „opmærksomheder“. Jeg betragter en genstand, og du observerer mit blik på genstanden; dette at jeg intenderer denne genstand berører din egen intenderen.

En dynamik, der lyder hen ad René Girards begarslogik, altså, at vores begar retter sig mod det, der begares af andre?

Det er vist et meget godt eksempel. Nu tager Girard først og fremmest fat i det erotiske register. Jeg ville tage fat i ethvert register og tale om en form for empati-mekanisme, som i øvrigt hos mennesket er forbundet med blikkets måde at fungere på i den menneskelige synsrutine, og den er forbundet med dette at vi anvender vores fingre deiktisk. Når jeg peger på noget, støtter jeg en ,blikkenes dynamik“, som allerede fungerer derved at $d u$ ser at jeg ser på noget, og derfor ser på det. Det binder os begge. 


\section{Blikdynamik? Men det kraver vel at der er noget $i$ verden for blikket at blive indfanget af,}

en blikattraktion?

Det forventer vi, medmindre mekanismen skuffes. Og det basale fænomen raffineres jo yderligere, når det bliver til en sproglig fokusering og ikke udelukkende en gestuel, okulær og deiktisk, ikke en finger- og øjenbevægelse, men en sproglig, referentiel mekanisme; når mekanismen bliver afhængig af vores symbolpraksis, vores symbolisering, som atter afhænger af empatimekanismen. Når symbolmekanismen træder ind, bliver opmærksomhedsstyringen kulturel, og så dannes der disse opmærksomhedsfællesskaber, som er langt dybere end erfaringsfællesskaber. De reguleres af en opmærksomhedens kulturelle stilistik: Måder at lægge mærke til ting på, at overse eller fremhæve ting systematisk, endnu inden man kan være sig det bevidst.

Hvis man for en stund følger denne tanke, kunne man da forestille sig at et obstrueret opmarksomhedsfelt altid vil vare eller blive helligt og/eller erotisk?

Jeg vil tro, at der er to intense standardfokuseringer inden for en kultur, hvoraf den ene er det erotiske og den anden er det religiøse; og ganske ofte vil de være forbundne. Religiøs opmærksomhed er jo meget ofte i sig selv koncentreret om erotiske fænomener, ligesom teologier derfor tematiserer hvordan man omgås seksualiteten. Det har formentlig at gøre med at vi her finder et universelt tabuemne, nemlig blufardigheden over for det nøgne. Det er meget pudsigt fordi vi i øjeblikket ser et relevant opgør med [Norbert] Elias' kulturbetragtninger. Elias sætter det berømte store skel, som mange har gentaget efter ham, mellem moderniteten og førmoderniteten, og tror at antikke og ikke-europæiske samfund, uanset de er antikke eller ikke antikke, ikke har disse tabueringer. Han tror at det er moderniteten der installerer dem. Det viser sig, at det ikke holder stik overhovedet. At tabueringerne $\mathrm{i}$ virkeligheden trækker et væsentligt læs ved dannelsen af blufærdighed og dermed styrbarhed og respekt og autoritet og så videre i samfund af enhver art. Dette at slå øjnene ned er en universel andagtsrutine, som udtrykker forholdet til det hellige. Den er i hvert fald parallel i det erotiske og i det religiøse, og det kan skyldes at det i sidste instans er den samme neurale rutine, der er tale om, jævnfør skabelsesberetningen.

Der er altid noget vi ikke må se; steder og objekter som må tilslфres eller over for hvilke blikkene må sankes.

Ja, for når vi så ser alligevel, fortolkes det i vores kultur som et syndefald. Det er irreversibelt. Man kan ikke ikke-se, hvad man ser. Man kan ikke ikke-have-set, hvad man allerede har set, og dermed er man skyldig i at have set, og det må man bøde for; bødens eller bodens størrelse kan der derefter forhandles om. Det er det, som bøjer de kristne nakker, sådan at de bliver arbejdsdyr, for de skal betale gælden. Alment har vi ved synet af nøgenheden irreversibelt overskredet et tabu. I vores seksualitet har vi altid gjort det og vi har formentligt overskredet et tabu hver gang vi har været glade, holdt fester for eksempel Specielt er der her et forhold, der vedrører menneskenes omgang med rusmidler. Det er et evolutionært interessant faktum, at alle de tidlige Cro-Magnon-kulturer, der kendes, også har været forbrugere af rusmidler. Rusmidler er midler til rituel overskridelse af tabuer, og glæden er en „,entusiasme“, hvilket betyder at her har man været for tæt på guderne og det bøder man for med bondeanger bagefter, det er hele pointen, og derfor bliver man så dygtig til at bøje sig for autoriteter. 


\section{Lyset}

Vi må ikke se... lyset, guddommelighed er jo forbundet med lyset...

Nej, og vi ser jo lyset alligevel, og bagefter er vi nødvendigvis skyldige. Det er meget praktisk for en kultur; det spiller den på. Der er nu nogle, som professionaliseres i kulturerne til at fortælle præcist hvad der skyldes - det skændes kulturerne meget om indbyrdes. Hvor meget der skyldes. Der skyldes ikke ret meget i den aktuelle, som nogle kalder den postmoderne, kultur. Vi tror, at samtlige tabuer er ophævet, der hersker blot en vis forvirring med hensyn til, hvad det er der skyldes. Enhver ved at der skyldes under alle omstændigheder. Depressionen viser sig i nutiden at være den helt store folkesygdom; den ytrer sig jo ikke mindst i skyldbevidsthed. En ubegrundet, uforståelig, mystisk skyldbevidsthed, som formentligt er genkomsten af en antropologisk grundkendsgerning. Altså at man føler at selve dette at man har set og har følt, at det gør en, i disse patologiske udgaver, ekstremt skyldig. Der findes jo også entusiasmetilstande inden for depressionen, den bipolære depression. Entusiasmetilstandene øger naturligt den skyldbevidsthed, der optræder ved den modsatte pol. Der er i øvrigt en aktuel publikation om depression - I sort (1999) - der omtaler dette fænomen.

Jeg kommer til at tanke på Goethe, der et sted siger: Mennesket er ikke bestemt til at se lyset, men til at se det belyste.

Ja, det er klart. Det er meget interessant dette med lyset. Det er endnu et fænomen, som den antropologisk interesserede semiotik må beskæftige sig med. Der er for vores kognition forskel på genstande, som ses, fordi de befinder sig i et oplyst rum - formentlig også vores mentale rum; når vi forestiller os noget, forestiller vi os det i en form for mentalt nærlys, men vi forestiller os helst genstandene som ikke selv værende lysende - og på den anden side genstande, som lyser af sig selv. Vi kender kontrastvis selvlysende legemer fra hellige oplevelser. Det er oplevelser af engle, oplevelser af genfærd, de lyser lidt svagere, men de lyser i mørket. Og ufoer, i nyere tid. Et selvlysende legeme - corpus gloriosus - har en status som helt naturligt skelnes fra et ikke-selvlysende. Derfor har himmellegemer, som lyser, jo til enhver tid været opfattet som hellige. Solen, månen, stjernerne. Alt hvad der lyser selv og kan ses fordi lyset udgår fra dem har en særstatus. Man kender det jo for $\emptyset$ vrigt også fra simple fænomener som kærlighed, hvor man oplever en aura omkring den elskede person. Da siger man mange mærkelige ting, man bruger metaforer, som guddommeliggør den elskede. Her har man ganske naturligt en hellighedsfunktion som i øvrigt udgør en af de store vanskeligheder i kærligheden, for det gør også, at man bliver skyldig i at overtræde et tabu, når man omgås den elskede; hvoraf nogle slutter, at det bedste derfor er at elske på afstand. Men det får vi ikke ret mange børn ud af! Mennesket er bygget på modsigelser. Det er det interessante. Uophørlige modsigelser, som ikke kan indløses på nogen måde. Det er det mest bemærkelsesværdige nye syn i den dynamiske semiotik: At det drejer sig om at forstå, hvilke bundter af modsigelser, mennesket kreativt er bygget af. Det drejer sig ikke om at løse modsigelserne med holistisk henblik på det ,hele menneske“. Det drejer sig om at se, hvilket bundt af flytbare modsigelser, vi består af. Heri består vores frihed, nemlig at vi kan redigere i disse indbyrdes modstridende dynamiske tendenser. Men for nu at forfølge pointen om lyset. når vi i moderne teknologi, i kommunikationsteknologiens elektriske fase, finder på at oplyse de ting, som vi nu fremhæver, for eksempel i reklamerne, så at disse reklamer sender 
os lysende, selvlysende udgaver af de genstande, der reklameres for, opretter vi jo dermed et helligt felt, og da bliver reklamebilledet et alterbillede, hvilket gør, at vi rent kognitivt udløser hellighedens mekanismer hos modtageren...

...eksempelvis?

Du ser for eksempel posters lyse fra skilte med indlagt elektrisk lys bag billedet, sådan at billedet selv lyser; det frembringer en modtageradfærd, som marketingsfolkene finder højst interessant, for det får folk til irrationelt at anskaffe sig ting, som de ikke har brug for. På samme måde som et lysende alterbillede får én til at sige ting som man ikke får noget ud af at sige. Man bryder i gråd, falder på knæ og fremsiger ting, som vi kalder bønner, bærer sig ejendommeligt ad og drager på korstog, som man ikke har nogen gavn af i øvrigt, blot fordi man er ramt af et selvlysende billede. Hver gang en mystiker har en erfaring, som kan bestemme hele resten af dette individs liv og gøre det til klosterstifter, som den Hellige Theresa, er der tale om et fænomen sammenligneligt med noget sådant; jævnfør også flammeskriften på væggen: Det er jo ikke en skrift, som belyses af et stearinlys i nærheden, det er jo en selvlysende skrift. Vi genkender i øvrigt fænomenet metaforisk, når vi siger, at noget er ,indlysende“. Når noget er indlysende, så lyser det selv ind i os. Det er uimodståeligt, fordi her har vi at gøre med noget, der kommer fra det helliges område. Når folk, også de intellektuelle i vores århundrede, har været så ubehageligt berørt netop ved industrisamfundets kommunikationsformer, marketing og reklamer, er denne uro og dette ubehag simpelthen evolutionært begrundet $\mathrm{i}$, at man her profanerer noget, som burde være forbeholdt hellige ting. Jeg kender til fænomenet fra en helt anden sammenhæng, nemlig fra universitetet. Når en underviser anvender en tavle, tænder eleverne lyset med en kontakt på væggen, hvilket făr den hvide skrift på den sorte tavle til at træde så meget frem, at man kan tage noter. Men når en moderne underviser, som netop har været i USA, kommer hjem og smækker en overhead med den samme meddelelse på en maskine, som sender grafikken op på en hvidt lysende skærms flade, får vi en helt anden adfærd, en underkastelsesadfærd, som simpelthen skyldes den samme selvindlysende mekanisme. Her skal man derfor være opmærksom på fænomenet, hvis man vil undervise. Man får en dialogisk deltageradfærd over for det ikke-selvindlysende tavlebillede, mens man får en adorationsadfærd over for overheadprojektionens indhold.

Universitetet versus Handelshфjskolen?

Ja, for dér er det ikke altid meningen, at der skal diskuteres, det er meningen, at der skal tilegnes. Og det man så gør er i grunden følgerigtigt: Man udnytter menneskets religiøst indbyggede rutiner, så man lærer stoffet som om det var Fadervor. Ikke som om det var en hypotese, som står til diskussion i kantinen.

Dette forhold løser måske et af marxismens grundproblemer: Det er sikkert derfor, guld blev et værdirepræsenterende metal: Simpelthen fordi det er blankt og kan opleves som selvlysende... Hvad i øvrigt med computerskærme?

\section{Verdens former}

Den franske matematiker og filosof René Thom, der blandt andet står for en matematisering topologisering af semiotikken-og som har varet en hyppig reference hos dig-blev 
en gang spurgt hvad videnskab er, og svarede, at al videnskab frem for noget andet er et studie af en fanomenologi. Er du enig i denne minimaldefinition?

Det kan man jo også kalde et husserliansk synspunkt, bortset fra at husserlianerne har været mere usikre. René Thoms realisme er interessant ved at fremhæve det forhold at den makroskopisk oplevede verden - ikke kun ,-skopisk“, i øvrigt, den er jo også givet lydligt og gennem alle de sanseintegrationer, der findes - er givet ved en formel oplevelse, hvorved vi informeres om former, der da bliver til komponenter i kognitive skemaer. Disse former informerer os både som figurativiteter og som dynamikker. Vi antager altså at en form er udstyret med krafter og netop bliver meningsfuld derved. Derfor skelner vi mellem billedet af en ting, en pibe hos Magritte, og selve tingen - fordi dynamikken ikke tages med over i billedet. Men når man forstår, hvad billedet er billede af, tilføjer man den indre dynamik i tingen og mellem den og dens omgivelser, disse kræfter som billedet jo ikke i sig selv besidder.

Den oplevede verden er en formel oplevelse, og i tilfaldet kunst er det først ved tilføjelsen af en dynamik, at den kunstneriske oplevelse indtraffer?

Det er selve den dynamiske rekonstruktion i udfyldningsarbejdet, der giver tingens billede mening. Et billede af en pibe kalder vi også en pibe, „dette er en pibe“, fordi vi automatisk antager, at rekonstruktionsarbejdet er muligt. Hvad angår den specifikt kunstneriske oplevelses genstand, beror den på særlig prekære dynamiske balancer.

Det vil sige, at hvis vi ikke er $i$ stand til at tilføje en dynamik, mangler vi en elementor menneskelig kompetence?

Ja, men den mangler vi faktisk ikke. Der er naturligvis en vis kulturel variabilitet i forbindelse med hvad man opfatter som værende et billede. Det betyder ikke, at vi ikke transkulturelt har de samme kompetencer til at rekonstruere, men blot at vi kun rekonstruerer

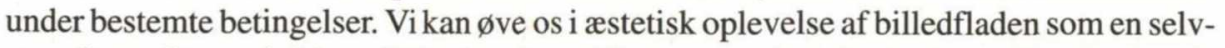
stændig realitet ved siden af billedets forestillingsrum - det billedet forestiller. Det kan vi $\emptyset \mathrm{ve}$ os i, og da får vi en særlig spændende dynamik mellem fladen og rummet i et billede; mens uøvede betragtere vil gå direkte til forestillingsrummet og måske sige, at det ligner eller ikke ligner, hvorfor det er et dårligt billede. Men René Thom er en spændende realist, for så vidt at han har været mere ontologisk beslutsom end mange kognitivister. For eksempel troede metaforforskerne længe at metaforerne dannede arbitrære mængder, som vilkårligt styrede den menneskelige begrebsdannelse; under et givet begreb ligger der blot en vilkårlig liste af metaforer. Men René Thom antager, at der under metaforerne som repræsentationer ligger skemaer som forestiller de ting, som metaforerne er om. Den billedmængde der optræder $i$ metaforen hidrører fra en reel, fænomenologisk tilgængelig kilde. Dyremetaforerne stammer fra oplevelser med dyr og kan slet ikke blive metaforer medmindre man har en dyrekategorisering i forvejen, det vil sige en direkte kategorisering af omverdenen. Her er realismen altså stærkere end i mange af de gængse metaforstudier. Man tror ofte, at blot man skifter metaformængden ud, får man et nyt begreb. Men man kan faktisk ikke arbitrært skifte metaforerne ud, for de skal være motiveret i selve det, de ,forestiller“ ifølge en dybereliggende, naturlig fænomenologisk realisme.

I lighed med realismen $i$ tegndannelsen?

Ja. Tegndannelsen, selve dette at der opstår en ekspressiv variant, et udtryk, af en betydningsmængde, et indhold, når den kommunikeres, er et semiotisk standardvilkår. Hvilket 
tegn der således opstår er mindre bestemt, en mere variabel sag, heldigvis, ellers ville verden være noget kedeligere end den er. Men de ting vi kan lægge mærke til er jo begrænsede af vores biologi, ligesom de er begrænsede af omverdenens morfologi. Man får således en morfologisk realisme. Vi bidrager givetvis til tingenes betydning alene ved at opleve dem, men man kan ikke opfatte dette bidrag som en konstituerende projektion af „vores“ oplevelsesformer på en uformet verden. Den radikale relativisme forestiller sig at verden i sig selv ikke har nogen form, men at vi oplever den sådan fordi vi projicerer. Dertil er at sige at vi, i hvert fald ifølge den thomske realisme, projicerer på noget, som vi ikke kan undlade at opfatte som tiltrækkende for projektioner.

Den menneskelige betydning griber $i$ sin dannelse altså så at sige ud efter allerede foreliggende former $i$ verden?

Præcis. Vi griber foreliggende salienser og de bliver pragnante for os, når vi har grunde til at opfatte dem prægnante på forhånd, fulde af en ,udstråling“, der angår os. Så nogle af prægnanserne er vores bidrag. Men for eksempel dette at visse legemer er selvlysende, beror jo på omverdenens egne uimodståelige prægnanser. Når vi opfatter den elskede som selvlysende er det givetvis en projiceret prægnans, men ikke alle prægnanser er projicerede. Jeg tror, at alle menneskelige vildfarelser har en realistisk kilde. Jeg tror også at der findes en god forklaring på hvordan nogle mennesker kan tro at de tror at verden er uformet. Nemlig dette at den eksistentielle del af verden er det. Vi fødes ind i verden og lever vores liv og kommer ud for en kaotisk mængde af begivenheder som vi samler på og ordner i en pæn narrativ orden, så vi kan fortælle vores historie i vores selvbiografi. Den vil omhyggeligt have udvalgt hvad der giver mening og udeladt det som kun er støj i forhold til hovedlinien. Den orden eller rækkefølge hvori vi oplever hvad et menneske nu kommer ud for af skuffelser og glæder og sorger er rigtignok kaotisk. Hvis man nu generaliserer fra den eksistentielle del af virkeligheden, det vil sige den intime del, den personlige, hen over den ikke-intime del af verden, indeholdende tyngdekraft, temperatur og lys og mørke og så videre, får man den ejendommelige anskuelse, som man kender fra eksistentialfilosofien, at verden som helhed skulle være kaotisk. Vi kender på en måde synspunktet fra vores store og mærkelige landsmand lingvisten Louis Hjemslev, som synes at hævde at tingenes form dannes af tegnfunktionen, idet den funktionelle binding mellem udtryk og indhold forvandler indholdsmeningen, tingenes oplevede væren, til en indholdsform, et formet indhold, som får os til at mindes det, der var før, som en ,substans“, der har fået sin form fra udtrykkets, der har kastet sin ,form“ over indholdet, som et net kaster sin inddelende skygge på en uinddelt flade - verden er på forhånd en uinddelt flade. Men hvis jeg ser en mand gå tur med hunden i snor, kan jeg ikke inddele på anden måde end i mand for sig, hund for sig og snor imellem dem, hvilket også er hvad sproget, syntaksen, siger. Sproget siger ikke, aldrig nogensinde, at jeg har et begreb svarende til en mand, en snor og en halv hund og et andet begreb der betyder den resterende del af hunden. Det ville være resultatet, hvis man fulgte Hjelmslev her.

\section{At interviewe sproget}

„Sproget siger ikke... “, siger du; andetsted har du talt om ,at interviewe sproget “, kunne du uddybe dette? 
Ja, det gør man ved at se, hvad sproget ,mener om“ forskellige ting, ved at se hvad sprog finder det umagen værd at finde enkle ord for. Ting man ikke finder det umagen værd at kategorisere bliver beskrevet med ordsammensætninger eller ordsammenstillinger. Men hvis du har et ord med en rod, så er det jo enklere for begrebet eller kategorien at håndtere dets betydning som én ting; det vil sige at dette er et udtryk for at sproget „,mener“ at du her har en væsentlig ting. Tænk hvis 'vand' og 'fisk' hed noget højst kompliceret omfattende en større samling ord med mangfoldige rødder; det ville betyde at vi ikke betragtede disse betydninger som særlig vigtige - lige så lidt vigtige som en 'halv hund'. Men en kultur uden hele hunde eller uden vand og fisk er ilde stedt.

\section{Etnografen interviewer sproget og får at vide at vand er vasentligt?}

Det ,synes“ sproget åbenbart. Hvad sproget har hurtige, fikse udtryk for, finder det centralt. Forhold som sproget har klodsede, indirekte udtryk for er specielle forhold, som de lærde da godt kan sige noget om, men som andre mennesker fint kan undvære, når de har travlt. Og i sprogets verden har de fleste travlt, undtagen de skrivende, klerkene. En sætning, en optimal sætning, tager tre sekunder, hvilket er det samme tidsspand som vores fundamentale opmærksomhedsvindue anvender, ifølge den revolutionerende hjerneforsker Ernst Pöppel; den tid det tager os at lægge mærke til at vi er til stede i en situation og har et perspektiv på den. Det skal gå hurtigt, og neurologisk set er tre sekunder allerede meget lang tid. Vigtige forhold opfattes af opmærksomheden på millisekunder og kategoriseres med det samme. Hurtige udtryk viser hvad der er vigtigt. Man kan derfor, interviewe" sproget om, hvad der er vigtigt. Man behøver vel at mærke ikke refleksivt at være enig med sproget. Men det er informativt at konsultere det; det oplyser os om indarbejdede intuitive opfattelser, som i hvert fald vores forfædre må have fundet centrale.

\section{Kulturernes jordbundne opgave}

En anden af dem, du ofte har citeret, og hvis bøger, du har oversat til dansk, er den franske filosof Michel Serres, der også har en af sine mange rødder i naturvidenskaben. Han har i en diskussion med Lévi-Strauss en gang sagt, at „kulturens opgave eller arbejde er vedvarende at adskille rum og derpå samle dem igen“. Med denne rummelige bestemmelse ligger han vel ovre i retning af en thomsk forståelse af ,kulturens “ opgave?

Det har jeg ofte tænkt at Serres egentlig måtte gøre. Det er svært at finde direkte referencer. Men det er rigtigt, at Serres’ verden befinder sig meget tæt på en rumligt og dermed kropsligt forankret opfattelse af det kulturelle. Det er også et spørgsmål som antropologisk har at gøre med menneskets forhold til territorier og steder - i forhold til hvilke vi er mobile, men også føler os bundet. Og det har at gøre med identitetsdannelse. Hvor mange øer er det, Danmark består af, ud over fastlandet? 474 ifølge Encyclopedia Universalis. Her skal der forbindes, og dannelsen af helheder af dele - det der kaldes mereologi - er en del af det menneskelige forståelsesudstyr, kognitionen. Dannelsen af helheder er en meget kompleks affære. Hvis jeg har et naturmassiv, som danner en kontinuitet, kan jeg dele det ved at tegne en stiplet linie tværs over det, så har jeg en mulig grænse. Denne grænse kan jeg markere med malede pinde, hvis jeg vil, og kalde ,grænsen“. Men det ser ud til, at vi foretrækker grænser som også er eller omfatter naturlige diskontinuiteter mellem naturelementer som land og vand. Historien har forsynet os med disse blandede løs- 
ninger, så vi undertiden må trække grænserne over uinddelte flader som for eksempel den sønderjyske. Det vil netop typisk være konfliktområder, mens derimod områder som folk finder st $\varnothing$ tte i for eksempel bjerge, floder, bliver ,naturlige“ grænser i den forstand at her hjælper virkeligheden os bedre med at danne helheder. Filosoffen Barry Smith har arbejdet systematisk med klassifikation af forskellige former for helhedsdannelser ud fra dette princip. Det er et fascinerende studie både for forståelsen af den menneskelige geografi og af hvordan vi overhovedet forstår en genstand som kan være internt artikuleret.

Naturen foreslår nogle granser, og menneskene foreslår desvarre somme tider nogle andre?

Vi taler om forskellen mellem bona fide-grænser, hvor vi er ,i god tro“ og hjælpes af naturen, som for eksempel grænserne omkring vores egen krop i forhold til det der ikke hører med til den, over for fiat-grænser, som er improviserede grænser, stiplede linier. Dannelsen af sådanne helheder er følelsesmæssigt vigtig for os og hører med til kulturfunktionen. Det har Serres jo understreget. At flytte en grænse bliver let et voldsomt følelsesanliggende for mennesker som identificerer sig inden for en kulturel kodeks, fordi denne er bundet til landskabet. Fædrelandskærlighedens grundlag er desværre naturligt, må vi sige. Vi kan ikke afskaffe nationalismen, men vi kan undlade at støtte den. Det er sikkert en sund intellektuel ting at gøre, men vi må også prøve at forstå hvorfor der overhovedet er noget sådant. Her har vi at gøre med noget som virkelig fokuserer på grænser, i modsætning til de konceptuelle kategoridannelser, der fokuserer på prototypiske kerner. Vi har for eksempel ikke et prototypisk Danmark midt i kortet og desuden lidt flosset Danmark ude til siderne. Vi har et Danmark klart markeret ved landegrænserne.

\section{Men hvorfor overhovedet nфdvendigheden af lukketheder, diskontinuiteter?}

Den har formentlig at gøre med den kulturelle funktions selvbeskyttelsesrutine, fordi man på de to sider af en grænse vil have forskellige opmærksomhedsproblemer, fordi man kommunikerer med mennesker, som praktiserer en anden kulturel kodeks.

Men kulturelt set er der jo i reglen tale om ganske flossede, vage overgange.

Det afhænger faktisk af mereologien, hvor flossede overgangene er. Nationer er kulturer omgivet af skarpest mulige overgange; derfor har Øresund været så stabilt i længere tid, mens det derimod var svært at holde Skåne, fordi der her var en fiat-grænse. Jeg tror man har generaliseret ud fra nationalgeografi til filosofiske definitionsfors $\emptyset \mathrm{g}$ i forbindelse med komponerede begreber. Man har tænkt at begreber havde en definerende mængde træk, der fungerede som en lignende skarp kritisk grænse. Den er kritisk i den forstand at man kun behøver at bevæge sig én meter til den ene eller den anden side, før man er et radikalt andet sted. Andethedens tiltrækkende tematik er simpelthen funderet i denne topologiske problematik. Den kulturelle funktion er måske den eneste antropologiske faktor som medfører patetisk insisteren på den kritiske grænse mellem det sammes sammehed og det andets andethed.

\section{Relativisme og artificielt dårligt humør}

Behovet for at fole sig hjemme er jo markbart i disse år, men vi har vel egentlig med en antropologisk konstant at gøre? 
Selv om man i enhver anden sammenhæng straks vil komme i tanke om alle de modsætninger, som findes hjemme, og hvor svært og problemfyldt det egentlig er at være ,hjemme“, sletter dette åbenbart ikke følelsen - de kulturelle „hjemveer“. Det har givetvis at gøre med at hvis man er i kategorien ,hjemme“, øges opmærksomhedsdybden i nærkommunikationen og man opfatter mere, netop endda rigeligt, af følsomme udvekslinger som for eksempel i relationen mellem generationer. Vi må tænke på forhold der angår mennesker intimt. Forældre og børn opfører sig anderledes når de er på ferie i udlandet end når de er hjemme, for hjemme forstærkes deres kodeks kraftigt af at alle andre følger automatiske normer som de selv følger.

Det vil sige, opmarksomhedsbredden bliver stфrre, når vi er ude og ikke rigtigt forstår, hvad der foregår omkring os, mens dybden til gengald bliver mindre og omvendt?

Elegant udtrykt. Poeter holder meget af at være ikke-hjemme, ude, Henrik Nordbrandt for eksempel. Det hænger sikkert sammen med at opmærksomhedsbredden ude akkompagneres af en dybde som her bliver selvfordybende. Det vil sige, at den som er ude fordyber sig i sig selv, mens den der er hjemme fordyber sig i alle andre, fordi de er så nemme at forstå, ikke kun sprogligt; sprog kan man jo vænne sig til. Men gestus, måder hvorpå alt elementært foregår. Selv flersprogede mennesker har det på samme måde; det er slet ikke et sprogligt problem, det er et følelsesmæssigt problem.

Det er simpelthen trattende på mere end én måde at vare „ude“?

$\mathrm{Ja}$, enerverende, selv-enerverende. Og den enervation er der mange kunstnere, der kan bruge. De finder simpelthen åbenbaringen når de er uden for landet, fordi deres nervesystem er enerveret, ualmindeligt og frugtbart selvoptaget.

Om antropologer er selvoptagne eller ej, skal jeg lade vare usagt, men den feltarbejdende antropolog bruger ofte sig selv som informant.

Man „observerer“ i så fald systematisk sit eget kognitive system, hvis man ellers kan vænne sig til det. Det er jo en disciplin, dette at være nogenlunde akkurat. Hvilket berører et alment spørgsmål: Hvad er videnskab? - det er vel resultatet af den samme nysgerrighedsfunktion som findes hos alle mennesker, men i videnskaberne er den bare renset for støj. I denne renselse ligger der således en vagtsomhed over for løse, spontane antagelser. Man skal være forsigtig med at støtte sig på spontan common sense, det ved enhver videnskabsdyrker. Man skal tvivle, selv hvor man spontant ville føle sig sikker. Det svarer til en oversætter, der slår et ord op, som han godt kender, for det kunne være der lige var en betydning eller nuance, han havde glemt. En ikke-professionel oversætter slår ikke op, medmindre han har et ord, han ikke kender. Man skal tvivle på langt mere end sædvanligt, også på det man er sikker på, tvivle så langt man kan holde det ud, meget længere end man plejer, uden for det professionelle felt - de omnibus dubitandum est - vel, man kan dog ikke tvivle på alt på en gang, det er livsfarligt, man ville blive ude af stand til at orientere sig i omverdenen; men succesivt kan man komme langt.

Altså, man må stole på en vis stabil mangde verden for overhovedet at tanke og handle $i$ den. Du pladerer for videnskabsmandens forsigtighed $i$ forhold til common sense; det inkluderer velsagtens også en forsigtighed i forhold til det almindelige sprog, herunder gangse metaforer. Er det det René Thom mener, når han siger, at $i$ videnskab galder det om at have kontrol med metaforerne? 
Det er den samme ting: Common sense er tykt belagt med metaforer. Der er visse metaforer man stoler på i hverdagslivet, og stoler på at andre stoler på, men her er man derimod i en situation, hvor man ikke stoler på, hvad andre stoler på; men man må gå et skridt videre og heller ikke stole på, hvad man selv stoler på. Det vil først og fremmest sige at man må være opmærksom på, at man uden at lægge mærke til det meget vel kan gå rundt og stole på ting, som kan vise sig at være vildledende støj og fejlkilder. Men bortset fra dette kan erkendelse overhovedet kun lade sig gøre, fordi der er en naturlig nysgerrighedsfunktion. Den meste forskning går ganske enkelt ud på at reanalysere hvad andre har analyseret og gentage andres observationer. Det er simpelthen systematisk mistillid og intet andet. Hvis man ytrede den samme systematiske mistillid i hverdagslivet ville man få store pragmatiske problemer, fordi folk ville tro man var paranoid. Men her har vi for så vidt en paranoia sat i system. Alt hvad der påstås er forkert indtil det modsatte er bevist.

„Systematisk mistillid“ siger du. Når nu relativismerne falder en for en, den ontologiske, den etiske, den kulturelle, da efterlades vi tilsyneladende kun med én, én vi kunne benavne forskningsstrategisk; altså det at vi for en stund - men blot for en stund-satter parentes om vores epistemologi, når vi studerer andre samfund. En strategisk begrundet dispensering af den nфdvendige videnskabelige fornuft.

En meget relevant bemærkning. Selv-relativismen består. Den er dog ikke en ontologisk relativisme... medmindre vi forsker i emnet: os selv som individuelle særegenheder. Vi må indse at genstanden er mennesket. Det er jo et absolut og ikke noget relativt, selv om Michel Foucault mente noget andet. Og med hensyn til mennesket antager vi, at det som genstand omfatter variabler og konstanter, og her er det vi må passe på med, hvad vi antager. Relativiseringen gælder antagelserne. Men det er ikke andet end hvad vi ville gøre hvis vi var i rigtigt dårligt humør en dag: så ville vi blive småparanoide, og alt hvad folk kom og påstod ville vi skrotte. Man kan sige, at videnskabelig disciplin består bare $\mathrm{i}$ at tilegne sig evnen til at være i artificielt dårligt humør! Det er jo derfor, mennesker bliver i så godt humør, når de finder noget, som de ikke kan afvise. Jeg blev selv i vældig godt humør, da jeg mente at forstå, at domæneteorien kunne tænkes at holde; så var der da noget af det jeg var med til at tænke, jeg ikke behøvede at afvise. Så oplever man straks den noksom bekendte videnskabelige entusiasme, ikke sandt - hurra, her er en konstant... Nu skal man også være forsigtig med at blive for glad! Da ender man som dogmatiker. $\emptyset$ velsen må da bestå $i$ at finde nye anspandtheder?

Nye tvivlsomheder, nye spørgsmål som man heldigvis kan blive i dårligt humør af.

\section{Humanvidenskab og naturvidenskab}

I dit forslag til en realistisk semiotik - og en realistisk antropologi - bliver det alligevel nødvendigt med nogle gransedragninger mellem humanvidenskaberne og naturvidenskaberne. Jeg har bemarket mig at du på det seneste har brugt Descartes til at trakke disse granser med?

For det første vil jeg sige, at en af de morsommere begivenheder i den senere tid har været Alan Sokals provokation i 1996, hvor han viser, at flirten med naturvidenskaberne 
fører til mærkelige ting i specielt den franske intellektuelle diskurs; en anvendelse af tilsyneladende naturvidenskabelige referencer der er så fejlbehæftet og alligevel så insisterende at man må undre sig over, hvad der dog foregår. Her drejer det sig rigtignok om en anvendelse af naturvidenskaberne som er stærkt selektiv. Det drejer sig om socialkonstruktivister og relativister, som forsøger at støtte sig på naturvidenskabsfolk, som skulle mene at verden er relativ, uformet og struktureret via projektion. Cultural studies-stilen hængt ud til afklapsning for manglende tvivlen. En ganske berettiget latterliggørelse af en selv-gratulerende dogmatik hos humanister.

Men han er jo også - og $i$ kraft af heftige fejllasninger og misforståelser - gået efter Michel Serres?

Men det er først og fremmest rigtige charlataner, Jacques Lacan og Julia Kristeva, som er gode eksempler på højtravende vås, men Jean Baudrillard er et lige så godt eksempel, og

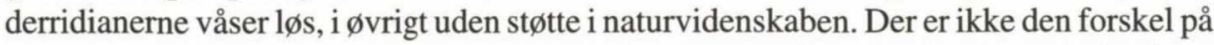
naturvidenskaberne og humaniora, at humaniora har ret til at sige hvad som helst. Man har desværre i vores århundrede praktiseret en sådan opfattelse af humanisme, at selve det at have en opinion om et eller andet, en eller anden kulturel begivenhed som man kan kommentere, generalisere ud fra på slap line, det er at bedrive humanistisk forskning. Den består i så fald af våsehoveder som salvelsesfuldt våser løs om hinandens vås, som er kulturelle begivenheder i sig selv. Den forskel vil jeg problematisere. Der er den ontologiske forskel mellem humaniora, dette pansemiotiske felt, og naturvidenskaberne, at vi i det humanvidenskabelige befinder os i en region af det virkelige, som vi kan kalde betydningens, meningens. Betydning er en slags virkelighed som rigtignok opfører sig anderledes end den materielle virkelighed. Forsker man i denne særlige form for virkelighed, som humanister og socialforskere gør, og som semiotikere gør tværgående, da forsker man ifølge nøjagtig det samme forskningsbegreb, som man anvender i naturvidenskaberne, men genstanden er forskellig, og man må tage hensyn til, at den er forskellig. Betydning er jo ikke en materiel genstand, som er bundet i tid og sted. Den er - sagt med Descartes - ikke af arten res extensa, men snarere af arten res cogitans. Vi har at gøre med for eksempel mentale skemaer til opfattelse af forskellige forhold, for eksempel intentionelle og kausale skemaer, som typisk udtrykkes af sprogets verber og indgår i deres semantik. Sådanne skemaer er jo ikke materielle, men de er ontologisk set naturgivne og eventuelt kulturelt specificerede formelle egenskaber ved bevidsthedens indhold, og man må fors $\emptyset$ ge at forstå dem med de midler som vi anvender på andre formelle fænomener, herunder matematik, logik, topologi, mereologi... Og der kan såmænd komme lige så streng videnskab ud af det, streng i den forstand at den kan holde regnskab med forskellen mellem begrundede og ubegrundede antagelser. Det tror jeg Sokal har leveret et godt bidrag til understregningen af. - Michel Serres er lidt af en enspænder; når han for eksempel henviser til termodynamikken, mener han virkelig termodynamikken i videnskabshistorisk forstand; han slæber den ikke rundt i manegen i et relativistisk cirkus.

Og Descartes...?

Selve forskellen mellem den form for virkelighed vi kalder betydning og den anden virkelighed hænger sammen med forskellen mellem bevidsthed og alt andet. Når det drejer sig om det metodologiske - det første var den ontologiske del af svaret - så hænger den sammen med, at hvis vi vil forstå bevidsthed, hvis vi vil forstå den del af emnet bevidsthed som har at gøre med dens indhold, altså betydning - bevidstheden kan være en slags 
teatermæssig scene i en metafor; de dramaer der udspiller sig på denne scene er så betydningen - hvis vi vil forstå dén, må vi nødvendigvis gå sådan til værks, at vi opfatter det oplevede og den så vidt mulig stringente redegørelse for det oplevede som en relevant kilde i forskningen. Nu ved vi på den anden side at bevidsthedens indhold har kilder uden for bevidstheden. For eksempel hvis jeg „oplever“ en stol lige nu, er det især fordi der faktisk er en stol her, et møbel som ikke har noget at gøre med min bevidsthed. Der er en bestemt artefakt her i min stue, som har bestemte formelle egenskaber, som min kognitive bevidsthed vælger at selektere i sanseintegrationen, apperceptionen. Det ligger uden for bevidstheden. Og selve den processering, der finder sted i integrationen af oplysninger gennem mine sanser og frem til det øjeblik, hvor jeg efter måske 300 millisekunder kategoriserer denne genstand som en stol, tilhører for så vidt stadig den materielle virkelighed. Men jeg oplever ikke sanseintegrationen. Hvis jeg vil vide, hvorfor jeg opfatter en ting på en bestemt måde, må jeg vide det både indefra og udefra. Det betyder for eksempel at bevidsthed og hjerne nok er to sider af den samme sag, men de bliver ved med metodologisk set at være to sider. Jeg kan ikke erstatte min oplevelse med en redegørelse for hvad der foregår i det neurale system. Det kan aldrig blive et spørgsmål om synapser, hvad jeg oplever, når det jeg oplever er en stol, en kvalitativ betydningsenhed. Men hvis jeg vil forstå hvordan betydningen basalt set bliver til og finder sted, for eksempel hvorfor det tager tre sekunder at opleve et fuldttonende øjeblik med alle de følelsesnuancer og perceptive aspekter, det har, må jeg tage den anden side med, den neurale side. Hvis jeg nu nægter at erstatte den ene med den anden, må jeg altså fastholde at både den ene og den anden side er relevante, og da har jeg en metodologisk dualisme. Min måde at forstå Descartes på er at påstå, at det er det, han siger. Mens jeg derimod vil opfatte det som en reduktionisme at sige som de klassiske fænomenologer, at det er kun den oplevede side, som er virkelig, mens ,hjernen“ er en fiktion; og en reduktionisme at sige, at det er kun den materielle side, der er virkelig. Den semiotiske virkelighed indeholder altså to regioner, den ene er den betydningsmæssige del og den anden den materielle del. De er begge virkelige, men det er to forskellige former for virkelighed, så her må vi forsvare en dualisme. Denne dualisme er indtil videre uopløselig. Som John Searle siger: ,indtil videre“ - hvis den kan opløses, så til lykke. Under alle omstændigheder vil de kreative betydningsdannelser der ustandselig foregår jo kun kunne spores retrospektivt $\mathrm{i}$ en neural forskning. Hvad var det, jeg oplevede? Mens det jeg oplever lige nu, det oplever jeg nu, og det er specifikt for det, det vil forblive specifikt for det, at det er lige nu, jeg oplever det. Lad os antage at, jeg får en frisk idé, og dette kan for en foregrebet retrospektiv anskuelse skyldes at der er to forskellige betydningsdannelser som integrerer, som danner et bestemt blend på et givet tidspunkt; men denne redegørelse vil kun være historien om min idé, mens derimod fænomenet selv kun kan foreligge på én måde, nemlig i den oplevende bevidsthed. Enten har jeg en ny idé eller også har jeg ikke en ny idé. Hvis jeg har en ny idé, så har jeg den nu. Det den modsatte side kan gøre rede for er hvad der vil vare sket. Denne forskel er uophævelig. Jeg kalder den metodologiske dualisme en cartesiansk anskuelse for at advare mod at kritisere Descartes for hårdt. Det motiv der har været til at kritisere Descartes hårdt fra kognitiv side, har jo været dette ganske uvedkommende at Noam Chomsky forsvarer ham. Men min opgave er ikke at forsvare Chomsky. Jeg er ikke Chomsky-fan, jeg er langt hellere en læser af barok-rationalisten Descartes. Den nævnte dualisme generer naturligvis de traditionelle fænomenologer, for deres ,livsverden" kan jo ikke deles ind på denne måde. Jeg har formentlig pådraget mig en konflikt 
med fænomenologien, som jeg stadig, uanset, finder er den mindst tåbelige filosofi i nutiden. Men jeg har en konflikt med den. Jeg støtter også mit synspunkt på en anden antagelse, der vedrører bevidstheden. Nemlig den, at i det levende nærværs tre sekundervindue har jeg faktisk tid til at udfolde en forskel mellem et olympisk syn på en situation jeg befinder mig i og mit eget synspunkt, min syns-vinkel, på situationen. Jeg oplever altså både at jeg har mit perspektiv, min vinkel og min særlige for-mig-hed i situationen og på den anden side det forhold at jeg kan se hvad situationen er eller må være uden for min for-mig-hed. Jeg kan nå at udfylde både en „olymp“ og en kropsligt baseret vinkling. Og denne olymp antager på forhånd at situationen har materielle egenskaber, så jeg ved for eksempel at hvis jeg pludselig føler et stik i hovedet, som jeg vil kalde hovedpine, og ser en stjerne - så ved jeg at denne stjerne er en for-mig-stjerne, men jeg ved også at olympen ville kalde den et neuralt fænomen, som kan skyldes at der er nogle neuroner, der fyrer, som ikke skulle, og det kan man gøre noget ved, men i så fald med materielle midler som for eksempel en hovedpinepille. Det ved vi jo alle sammen. Vi accepterer jo at vores bevidsthed sidder i hjerner, ellers ville vi jo finde det meningsløst at spise hovedpinepiller. I hvert fald kan man sige, at menneskeheden plejer at være cartesiansk om mandagen, fordi der har den nemlig tømmermænd.

\section{Vestlig videnskab: en kognitiv stilart, der kan læres}

Nuvel, ville en ikke helt uforudsigelig indvending lyde: alt det du siger, kan jo ikke undsige sig at vare formuleret inden for en vestlig videnskabelig tradition!

$\mathrm{Ja}$, men det er jo et vilkår, som formentlig ændrer sig hurtigt i vore dage, hvor videnskabsdiskursen har gode teknologiske muligheder for at blive verdensomspændende. $\mathrm{Nu}$ får vi jo masser af asiatiske bidrag og vi får indiske bidrag og inderne er fantastiske udi datalogien. Vi får jo multikulturelle indspil som aldrig før. Heldigvis, for det gør forskningen til et meget spændende sted at være. Det kan godt være at vi historisk må kalde denne rensede nysgerrighed, som vi kalder videnskab, for vestlig, men i sin struktur er den jo bare en kognitiv stil, som er tilgængelig for alle mennesker. Det er en kognitiv stil, som i Europa har været trukket i forgrunden, i øvrigt blandt meget andet fordi den jødiske kultur har spillet en meget stor rolle som udfordring og bidragyder. Både som udfordring på den måde at andre har måttet tage stilling til den, og den jødiske gudstjeneste omfatter jo intelligensudøvelse. Jeg tror i virkeligheden at den jødiske tabuering af alt muligt fører til forestillingen om at der er grænser og man vil gerne vide, hvad der foregår på den anden side, og det øger nysgerrigheden. Det er blandt andet også det der motiverer sådan noget som den seksuelle nysgerrighed som førte til psykoanalysen, der jo er et jødisk forehavende, videnskabssociologisk. Og tabueringer er gode kausale skemaer: Her foregår noget, vi ved ikke hvad - vi ser nogle mærkelige virkninger, men årsagen er utilgængelig. Men nu bryder vi lige det tabu, og så prøver vi at finde årsagen. Vi ved godt at det er helligbrøde og det soner vi bagefter.

\section{I videnskabens navn?}

I nysgerrighedens navn, ja. Der er steder i verden, hvor vi ikke kan komme hen lige nu, og dem interesserer vi os særlig meget for. Det er en af de etniske grundholdninger, som fører til at nysgerrigheden bliver hysterisk forhøjet på nogle felter. Hvis vi har noget, vi 
ikke forstår, så har vi en udfordring, og samtidig er studiet af det, vi ikke forstår, en art gudstjeneste i den forstand at vi her har at gøre med en religion, der har den paradoksale egenskab, at bruddet med tabuet udgør en slags ritual. Jeg går ind på det hellige område og besudler det for så vidt, men det skal jeg jo netop i ritualet til guds ære. Det er noget helt andet, kan man sige, end Erasmus af Rotterdams gudsforhold, som siger at mennesket skal indse sin dumhed og menneskene ydmygt forenes i deres andægtige dumhed.

Videnskab som en form for systematiseret helligbrøde, som den hvide mand skyldstynget dyrker?

Videnskab som en virkning af en bestemt religiøs holdning. Vi plejer jo at betragte denne berømte vestlighed som en form for skyldmotiv. Hver gang vi fremhæver det vestlige, skal vi føle dårlig samvittighed; men nu har vi jo diskuteret hvad dårlig samvittighed er, det er under alle omstændigheder en af de vigtigste motorer i menneskelivet. Ikke fordi andre, ikke-vestlige mennesker ikke kan føle dårlig samvittighed, men vestligheden har direkte dyrket den. Men andre kan udmærket lære at gøre det. Hvis de ikke lærte det, blev de jo ikke videnskabsfolk!

For uddybelse af ovenstående se blandt andet:

Brandt, Per Aage

1995 Morphologies of Meaning. Århus: Aarhus University Press.

1998 Tegn, ting og tanker - semiotiske essays. København: Basilisk Sigma. 
